\title{
The National Commission On Fiscal Responsibility And Reform: How Its Report Can Impact Marginal Tax Rates
}

Steven R. Ferraro, CFA, Ph.D., Pepperdine University, USA

Richard W. Powell, CPA, J.D., Ph.D., Pepperdine University, USA

\begin{abstract}
The United States government has a serious budget problem. In 2010 President Barack Obama created the National Commission on Fiscal Responsibility and Reform to deal with the problem by identifying policies to improve the fiscal situation. Among the Commission's recommendations was a proposal to modify payments under Social Security. For most recipients, the modifications would decrease Social Security benefits although benefits would increase for the poorest quintile of recipients. The purpose of this paper is to construct a model for evaluating the proposed shift in Social Security payments. From the perspective of Social Security recipients, the model shows the cutbacks as the partial loss of an annuity stream, as the loss of a lump sum that is capable of generating the partial annuity stream, and as a tax increase for the remainder of the recipients' working years as they deposit a special tax into a retirement account designed to replace the lost benefits.
\end{abstract}

Keywords: National Commission on Fiscal Responsibility and Reform; Social Security; marginal tax rates

\section{INTRODUCTION}

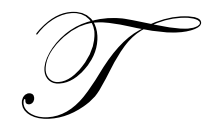

he United States government has a serious budget problem. The problem is largely related to an aging population and rising health costs. In 2010 President Barack Obama created the National Commission on Fiscal Responsibility and Reform (Commission) to deal with the problem by "identifying policies to improve the fiscal situation in the medium term and to achieve fiscal sustainability over the long run." (Commission Charter, p.1)

Among the Commission's recommendations was a proposal to modify payments under Social Security. Generally, for most recipients, the modifications would decrease Social Security benefits although benefits would increase for the poorest quintile of recipients. The purpose of this paper is to construct a model for evaluating the proposed shift in Social Security payments. From the perspective of Social Security recipients, they can view the cutbacks as the partial loss of an annuity stream, as the loss of a lump sum that is capable of generating the partial annuity stream, and as a tax increase for the remainder of their working years as they deposit this special tax into a retirement account designed to replace the lost benefits.

The remainder of this paper discusses the workings of the Commission, its recommendations related to Social Security payments, and a model for understanding the proposed modifications for Social Security. The model is useful for people who review their annual Social Security letters that show estimated benefits. The Commission's recommendations for cutbacks in benefits can reduce the recipients' current annual net income since they will need to allocate more personal funds to savings if they wish to reconstruct their retirement plan.

\section{THE NATIONAL COMMISSION ON FISCAL RESPONSIBILITY AND REFORM (COMMISSION)}

The Commission had 18 members with 10 Democrats and 8 Republicans. The president appointed six members drawn from both political parties while Republican and Democratic congressional leaders each appointed 
six elected members. The President sought a supermajority of 14 votes to formally endorse the commission's report. Although only 11 voted in favor of the report, there was majority support and it came from both political parties as well as from liberal and conservative members of the Commission.

The Commission charter required the proposal of "recommendations that can improve the long-run fiscal outlook, including changes to address the growth of entitlement spending and the gap between the projected revenues and expenditures of the Federal Government. " (Commission Charter, p.1) The Commission viewed the federal government's budget problem from two perspectives. First, the annual deficits have been large with a projected deficit of $\$ 1.227$ trillion for 2011. (Report of the National Commission on Fiscal Responsibility and Reform - (Report), p.63) Second, the federal government has accumulated debt of $\$ 10.168$ trillion as of 2011. This federal debt has risen from 33\% of Gross Domestic Product (GDP) in 2001 to 67.1\% of GDP in 2011. (Report, p.63, p.10)

The Commission's Report described the looming fiscal crisis, summarized its guiding principles, and then described its plan. The plan covered: Discretionary Spending Cuts, Tax Reform, Health Policies, Other Mandatory Policies, Social Security, and Process Reform. This paper focuses primarily on Social Security.

\section{THE COMMISSION'S DISCUSSION OF SOCIAL SECURITY}

The Report summarizes the current state of Social Security, which is the foundation of economic security in America. Created in the 1930s, Social Security began when the average life expectancy was 64. Demographics have changed. Today life expectancy is 78 and Americans on average spend 20 years in retirement. In 1950, there were 16 workers per beneficiary. Today there are only 3 and by 2025 it will be 2.3 . These changes are bringing Social Security to the edge of insolvency. Today the program is spending more on beneficiaries than it is collecting in revenues. Without modifications, the program's trust fund will be fully exhausted in 2037.

The Commission's recommendations for saving Social Security include: reductions in Social Security payments for higher earners; increased payments for lower earners; enhanced benefits for the very old; a gradual increase in the early and full retirement ages; a hardship exemption for those who cannot work beyond 62; increases in the taxable maximum to cover 90 percent of wages by 2050; an improved measure of CPI; mandatory coverage for newly hired state and local workers after 2020; better counseling for future beneficiaries; and broad dialogue on the importance of personal retirement savings.

This paper will focus on the modifications to Social Security payments. Except for earners in the lowest quintile, the Commission favors reductions from scheduled payment levels.

\section{MODIFICATIONS IN SOCIAL SECURITY PAYMENTS}

The Report provides tables showing recommended modifications to scheduled payment levels. The citizen with average lifetime income of approximately $\$ 38,000$ (the median in 2010) would see the scheduled benefit decrease from approximately $\$ 18,000$ per year to $\$ 16,344$, a $9.2 \%$ decrease. For higher earners, the reductions are higher on a percentage basis. The lowest quintile actually sees an increase in benefits. The Commission wants to increase "progressivity," which is a term frequently used in the analysis of tax policy. The progressive goal is to shift more benefits to the lower earners and away from the higher earners. This tax perspective will be important later in this paper.

It is notable that the Report provides an extensive discussion of the current, intense level of progressivity in the Social Security program. For example, current law provides individuals with benefits capable of replacing $90 \%$ of the first $\$ 9,000$ of (wage-indexed) average lifetime income and $32 \%$ of the next $\$ 55,000$. The replacement percentage dwindles to $15 \%$ for the income range of $\$ 64,000$ to $\$ 107,000$. With its new recommendations, the Commission favors more progressivity with the upper income ranges falling to $5 \%$ replacement by 2050 . At the same time the taxable maximum would increase from $\$ 106,800$ in 2010 to $\$ 190,000$ in 2020 . An already progressive system would become much more progressive. 


\section{A MODEL FOR UNDERSTANDING THE PROPOSED CHANGES IN SOCIAL SECURITY BENEFITS}

As mentioned above, the median Social Security recipient would see a scheduled benefit decrease from approximately $\$ 18,000$ per year to $\$ 16,344$, for a reduction of $\$ 1,656$. With an average life expectancy during retirement of 20 years as noted in the Report, the recipient is losing an expected annuity of $\$ 1,656$ for an expected 20 years. Since many recipients are taxed on only $85 \%$ of their Social Security payments, a replacement annuity would need to generate $\$ 1,762$ per year if the tax rate is $30 \%$ (Note here are the computations that solve for $\mathrm{X}$ as $\$ 1,762$. Solve for $\mathrm{x}$ : $1656-[(.85 * 1656) * .3$ tax rate $]=\mathrm{x}-(\mathrm{x} * .3))$. Using an interest rate of $2 \%$, the recipient would need a lump sum of $\$ 28,811$ at retirement to replace the annual loss in Social Security benefits. The $2 \%$ interest rate is based on purchasing an annuity product from an insurance company with a 20 year expected life span but with the risk of a potential longer life. If a recipient has 10 years to save up for the lump sum, the annual deposits at the end of each period into an IRA or $401-\mathrm{k}$ with an interest rate of $6 \%$ would need to be $\$ 2,185.83$. If the recipient had steady income of $\$ 38,000$ over the 10 year period, he must set aside $5.75 \%$ of his income $(2,185.83 / 38,000)$ to build up the lump sum. The deposits into an IRA or 401-k are deductible and therefore the burden is $2,185.83$ - tax benefit of $(2,185.83 \mathrm{x}$ tax rate of .3$)=1,530.08$. Then the increase in his marginal tax rate is $4.03 \%$ as he tries to reconstruct his retirement plan. (Note: $1,530.08 / 38,000=.0403$ ).

\section{CONCLUSION}

The Commission's plan to remedy the federal government budget problem can impact Social Security recipients. The Report favors certain reductions in Social Security benefits. The recipients who wish to maintain their retirement plans must refill the lost benefits with their personal savings. These savings act as a tax on the recipients' income over the years that they deposit funds into an account to make up for lost Social Security benefits. The Commission refers to its plan as progressive, and this impact can be seen in the effective increase in the median recipient's marginal tax rate while, at the same time, lower earners actually see a decrease in their marginal tax rate due to their proposed increase in Social Security benefits. The low earners can deposit less into their personal retirement accounts and yet maintain their overall retirement plan. High earners experience an even greater percentage loss in benefits than the median earner and therefore also suffer an effective increase in their marginal tax rate.

\section{BIOGRAPHY}

Steven R. Ferraro, CFA, Ph.D.: Dr. Ferraro is an Associate Professor of Finance at the Graziadio School of Business and Management, Pepperdine University. His teaching responsibilities are primarily in the school's MBA program.

Richard W. Powell, CPA, J.D., Ph.D.: Dr. Powell is an Associate Professor of Accounting at the Graziadio School of Business and Management, Pepperdine University. His teaching responsibilities are primarily in the school's MBA program.

\section{REFERENCES}

1. The National Commission on Fiscal Responsibility and Reform. The Moment of Truth: Report of the National Commission on Fiscal Responsibility and Reform. The White House, Washington, D.C., December 2010. http://www.fiscalcommission.gov/sites/fiscalcommission.gov/files/documents/TheMomentofTruth12_1_20 $\underline{10 . p d f}$

2. Hoffman, W., Smith, J. and Willis, E., Individual Income Taxes 2011 Edition. Mason, OH: SouthWestern Cengage Learning, 2011.

3. Scholes, M.S., Wolfson, M., Erickson, M., Maydew, E.L., and Shevlin, T., Taxes and Business Strategy: A Planning Approach. Upper Saddle River, NJ: Prentice Hall, 2009. 
NOTES 